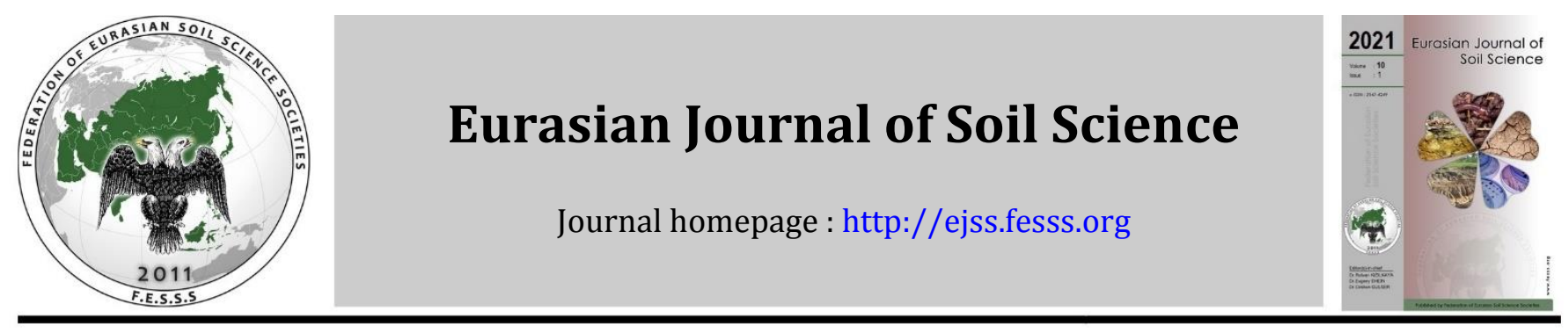

\title{
Laboratory assessment of soil respiration rates under the impact of ornithogenic factor in Antarctic region
}

\section{Ekaterina Chebykina (Maksimova)*, Ivan Alekseev, Evgeny Abakumov}

Department of Applied Ecology, Faculty of Biology, Saint-Petersburg State University, Saint-Petersburg, Russia

\section{Article Info}

Received : 07.10 .2020

Accepted : 15.01 .2021

Available online : 25.01 .2021

\section{Author(s) \\ E. Chebykina* \\ I. Alekseev \\ E. Abakumov}

* Corresponding author

\begin{abstract}
SOM stabilization rates were estimated in the soils of Antarctic region in case of influence of ornithogenic factor. Soils in large penguin clusters, near nests of Stercorarius sp., as well as soils located in geochemically subordinate positions (also often are visited by birds) were found to be characterized by an increased content of carbon and nitrogen with a rather narrow ratio of $\mathrm{C} / \mathrm{N}$. The $\mathrm{pH}$ values decreased in ornithogenic soils due to the organic acids that produced plants (mosses, Deschampsia antarctica) inhabit these soils and the decomposition products of the organic matter guano. The amount of $\mathrm{CO}_{2}$, in general, released over the entire experiment period is quite large for both ornithogenic and non-ornithogenic soils. $\mathrm{CO}_{2}$ emission rates were the highest in ornithogenic soils. Ornithogenic soils of the studied area are characterized by the most stabilized organic matter. Thus, the avifauna favors and increases the rate of the mineralization process by several times. An acceleration in the organic matter mineralization rate leads to an increase in nutrients amount available to plants, as in the case of the studied soils. The quality of initial SOM is of a great importance in post-ornithogenic environments. Therefore, further researches of $\mathrm{CO}_{2}$ emissions rates are needed to characterize post-ornithogenic dynamics and develop an approach to model this process.
\end{abstract}

Keywords: Antarctic region, $\mathrm{CO}_{2}$ emission, mineralization rate, ornithogenic factor, soil respiration.

(C) 2021 Federation of Eurasian Soil Science Societies. All rights reserved

\section{Introduction}

Soil organic matter ( $\mathrm{SOM}$ ) mineralization and $\mathrm{CO}_{2}$ emissions from soil significantly influence on a global carbon cycle and ecosystem stability. For this reason, great attention has been paid to this topic already (Debasish-Sasha et al., 2014; Bruun et al., 2015; Muñoz-Rojas et al., 2015; Novara et al., 2015).

Soils of Arctic and Antarctic regions contain maximum SOM stocks within the whole pedosphere, therefore, they are of a great importance in global carbon circulation and stabilization (Schuur et al., 2015; ParrasAlcántara et al., 2015; Peng et al., 2015). At the same time, SOM stocks in the Antarctic region are underestimated along with the Arctic region. It is due to the data lack for many areas of this continent, due to the high content of stones in the soils and the carbon content high variability in the fine earth (Abakumov, 2010; Yu et al., 2012; Abakumov and Mukhametova, 2014; Wasak and Drewnik, 2015; Abakumov et al., 2016). Antarctic soils are different in their morphology, chemistry, texture and mineralogical composition (Abakumov et al., 2018; Dmitrakova and Abakumov, 2019) as well microbiome structure (Alekseev et al., 2020). Particularly, Antarctic soils have a low content of soil TOC but it is different in various areas and soils. Soil TOC content has a wide range: from minimum levels (close to 0\%) in a humic regolith soils (Campbell and Claridge, 1987; Ugolini and Bockheim, 2008; Bockheim, 2013) to 3-4\% in soils under mosses, lichens, and cereals (Simas et al., 2008; Abakumov, 2010), or in some areas formed under guano it reaches up to 30$40 \%$ of organic matter (Simas et al., 2007b).

https://doi.org/10.18393/ejss.868088

http://ejss.fesss.org/10.18393/ejss.868088 
Ornithogenic soils are a special type of soil formation that is characteristic primarily for ecosystems of the Southern Hemisphere (Abakumov, 2010), although these soils are regularly found in the northern polar biome (Ivanov and Avessalomova, 2012). Ornithochoria was shown (Parnikoza et al., 2016) to be quite important in plant remnants redistribution in the Antarctic region because a significant number of variably composed organic material are transported by birds within inland landscapes. Previously, a specificity in morphological structure of ornithogenic soils was established (Abakumov, 2014b), features of soils micromorphological and mineralogical composition under bird colonies were revealed (Abakumov, 2014a), and features of ornithogenic soils geography of the Northern and Southern hemispheres were shown (Abakumov, 2010; Abakumov and Lupachev, 2011/2012; Ivanov, 2013; Pereira et al., 2013), classification aspects were clarified (Parnikoza et al., 2015), and a development of soils in post-ornithogenic succession was described (Pereira et al., 2013; Abakumov, 2014b; Abakumov, 2018; Alekseev and Abakumov, 2018). However, further researches characterized SOM composition, its structural compounds and their distribution in Antarctic ornithogenic soils are needed as published data on this topic are rare.

Huge organic matter pools nowadays are affected to microbial degradation (Schuur et al., 2015) and other environmental risks (IPCC, 2007; Rein, 2013, Tsibart et al., 2014; Zaccone et al., 2014) due to global climate changes and subsequent upon it permafrost degradation. Polar environments SOM is a source of vulnerable carbon that is quite sensitive to remobilization because of increasing temperatures (Schuur et al. 2015; Ejarque and Abakumov, 2016).

Field and laboratory experiments (Zhao et al., 2012) are usually used for an evaluation of organic carbon mass emission loss. Possible mineralization losses from ornithogenic and non-ornithogenic soils can be assessed by controlled laboratory experiments. These methods are necessary for analysis of an apparent stability of SOM and its' mineralization losses and for prediction the possible stability and losses of organic carbon in soils of polar environments. At the same time, data obtained in controlled laboratory experiment and from field experiments (e.g., closed chambers method) are not comparable between each other. Nevertheless, data obtained in unified conditions can be used for further simulation modeling of SOM transformation.

The aim of this study is to investigate the soil organic matter mineralization (carbon mineralization rates and $\mathrm{CO}_{2}$ emissions) in Antarctic soils of different origin by means laboratory incubation.

\section{Material and Methods}

\section{Study sites}

Soils subjected to a significant ornithogenic influence and non-subjected, were studied in terms of soil properties and $\mathrm{CO}_{2}$ emission intensity: plots in large penguin clusters, near nests of Stercorarius sp., as well as plots located in geochemically subordinate positions (also often are visited by birds) and accumulating nutrients as a result of redistribution in the relief. The studies were carried out on King George Island (Fildes Peninsula) and on the specially protected natural area (SPNA) of Ardley Island (South Shetland Islands). A location of the sites is shown in Figure 1.
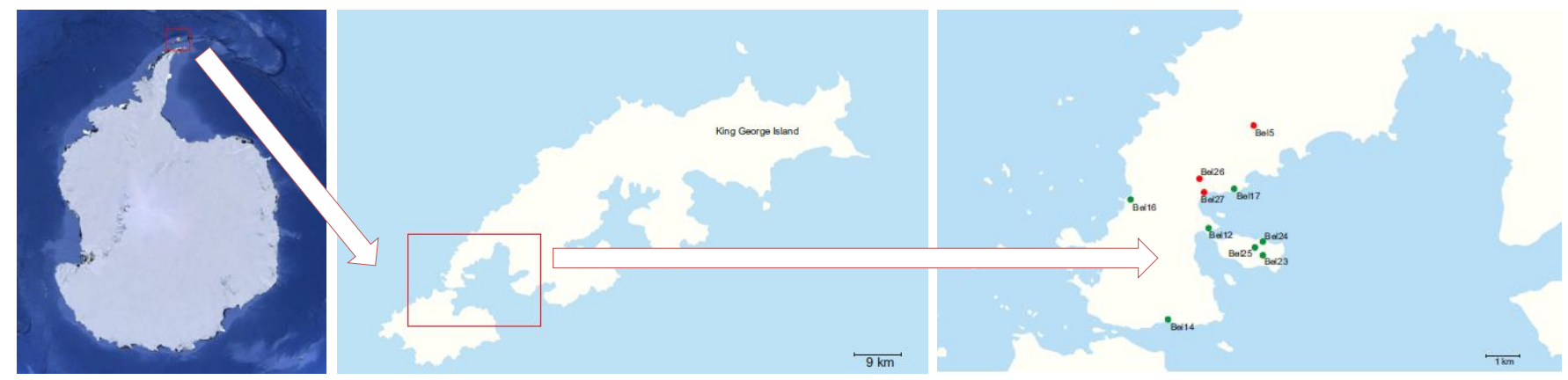

Figure 1. Location of study sites. Green circles - ornithogenic substrates, red circles - non-ornithogenic substrates.

King George Island is the largest island of South Shetland Islands archipelago (Figure 1). A relief of a southeastern part of the island is strongly dissected, has a number of bays. Most of the island is covered by a glacier. Numerous hills are composed of volcanic rocks (strongly eroded). According to eco-climatic zoning, King George Island refers to the Antarctic Peninsula in a part that is located north of the isotherm of average annual temperatures of $-1^{\circ} \mathrm{C}$. The island is located in the natural zone of Maritime Antarctica (Terauds et al., 2012). Soil formation is largely possible only at the tops of the hills and remnants, and also in the coastal parts characterized by a milder climate. Basalts, tuffs and andesites are parent materials, periglacial plots are covered by some fluvioglacial materials and moraines, while coastal areas are occupied by maritime sands 
and gravels. Mosses, lichens, algae are typical for most of the island's habitats. In some parts of the island, two species of vascular plants occur - Colobanthus quitensis and Deschampsia antarctica. Seabirds, penguins and seals are abundant in habitats of the coastal island, and play a crucial role in soil development (Michel et al. 2006; Simas et al. 2007a).

Ardley Island is located on a south-west coast of King George Island, $500 \mathrm{~m}$ east of the Fildes Peninsula coast in Maxwell (Fildes) Bay. Mean annual air temperature (MAAT) at King George and Ardley Island is about $2.3^{\circ} \mathrm{C}$; mean annual wind speed is $9.3 \mathrm{~m} / \mathrm{s}$; annual precipitation $-729 \mathrm{~mm}$. The area is represented mainly by andesite-basalt lavas and tuffs belonging to the Tertiary. Several elevated terraces-beaches are also described. Due to high biodiversity of Ardley Island it is designated as Antarctic Special Protected Area (ASPA). A wide variety of seabirds arrive in the area during the breeding period (11 species) or molting. Ardley Island is also characterized by a highly developed and noticeable flora, including several species of vascular plants, lichens and mosses. The most common lichens at studied plots are Usnea gen. and Himantormia lugubris, as well as Xanthoria sp., Rinodina sp., Placopsis sp., Buellia sp., Haematomma sp., and Caloplaca sp., which occupied mostly the higher parts of Ardley Island.

Soil identification was carried out using the "Classification and Diagnostics of Soils of Russia" (2004) (Shishov and Tonkonogov, 2004) and the World Reference Base for Soil Resources (FAO 2015) (WRB, 2015). Both classification schemes can be applied to the soils of Antarctica, but are clearly insufficient to describe the entire diversity of soils in the region. The studied ornithogenic soils are distinguished by a specific morphological structure of the soil profile, which is often represented by the following set of soil horizons: peat horizon - organic dark gray or dark-brown horizon and median horizon. Characteristic of studied soil and their horizons are given in Table 1.

Table 1. Characteristic of studied plots and soils.

\begin{tabular}{|c|c|c|c|}
\hline Plot & Depth, cm & Description & Soil horizons description \\
\hline \multicolumn{4}{|c|}{ Ornithogenic soils } \\
\hline Bel 12 & $0-2$ & $\begin{array}{l}\text { The coast of Maxwell Bay, sand spit leading } \\
\text { to Ardley island. } \\
\text { The plot on the coast, covered by moss } \\
\text { vegetation }(20 \times 30 \mathrm{~m}) .\end{array}$ & $\begin{array}{l}\text { Peat horizon. } \\
\text { Brownish color of plant debris. } \\
\text { Low decomposition degree. }\end{array}$ \\
\hline Bel 12 & $2-12$ & $\begin{array}{l}\text { Soil name (WRB/RSCS): Histic Lithic } \\
\text { Cryosol/Peat } \\
\text { Lithozem underlain by permafrost }\end{array}$ & $\begin{array}{l}\text { Brownish-grey horizon. } \\
\text { The abundance of rounded boulders. } \\
\text { Sandy loam. }\end{array}$ \\
\hline Bel 14 & $0-2$ & \multirow[t]{2}{*}{$\begin{array}{l}\text { Fildes Strait southwest coast. } \\
\text { A vast }(150 \times 8 \mathrm{~m}) \text { area covered with moss } \\
\text { vegetation and reaching along the coast. }\end{array}$} & $\begin{array}{l}\text { Peat horizon. } \\
\text { Brownish color of plant debris. } \\
\text { Low decomposition degree. }\end{array}$ \\
\hline Bel 14 & $2-15$ & & $\begin{array}{l}\text { Dark grey horizon. } \\
\text { The abundance of rounded boulders }(5-20 \\
\mathrm{cm}) \text {. } \\
\text { Sandy loam. }\end{array}$ \\
\hline Bel 16 & $\begin{array}{l}\text { Deschampsia } \\
\text { antarctica }\end{array}$ & $\begin{array}{l}\text { CHN (Chinese Antarctic Program) } \\
\text { monitoring site on top of a rocky highwall on } \\
\text { the shore of the Drake Strait at the Biologists } \\
\text { Bay. Deschampsia antarctica grows by } \\
\text { curtains, moss cover grows sporadically. } \\
\text { Fine detrital material is on the surface. } \\
\text { Soil name (WRB/RSCS): Grey-Humus Lithic } \\
\text { Cryosol/Grey-Humus } \\
\text { Lithozem underlain by permafrost }\end{array}$ & $\begin{array}{l}\text { Grey-humus horizon. } \\
\text { Taupe. } \\
\text { Medium-textured loam. } \\
\text { Inclusion of rotted rock. }\end{array}$ \\
\hline Bel 17 & $0-2$ & \multirow{2}{*}{$\begin{array}{l}\text { Surroundings of Bellingshausen Station, King } \\
\text { George Island. } \\
\text { Wet valley between rocky highwall. } \\
\text { Waterlogging. A projective cover of moss } \\
\text { cover is about } 50 \text { percent. } \\
\text { Soil name (WRB/RSCS): Histic Stagnic } \\
\text { Cryosol/Peat Gleyic } \\
\text { Lithozem underlain by permafrost }\end{array}$} & $\begin{array}{l}\text { Taupe horizon. } \\
\text { Medium-textured loam. } \\
\text { Lumpy and clumpy. }\end{array}$ \\
\hline Bel 17 & $2-7$ & & $\begin{array}{l}\text { Gley horizon with redoxymorphism signs. } \\
\text { Glaucescent-gray with stripes of } \\
\text { redoxymorphic material (mainly in the } \\
\text { upper part of the horizon). } \\
\text { Medium-textured loam. } \\
\text { Lumpy structure. }\end{array}$ \\
\hline
\end{tabular}


Table 1. continue

\begin{tabular}{|c|c|c|c|}
\hline Plot & Depth, cm & Description & Soil horizons description \\
\hline \multicolumn{4}{|c|}{ Ornithogenic soils } \\
\hline Bel 23 & $0-1$ & $\begin{array}{l}\text { A mild hillslope in the central part of Ardley } \\
\text { Island. } \\
\text { A penguin nesting site is on a nearby rocky } \\
\text { highwall. } \\
\text { The surface is covered by alga Prasiola crispa. }\end{array}$ & $\begin{array}{l}\text { Ornithogenic horizon. } \\
\text { Grayish-glaucescent. } \\
\text { Ornithogenic soil processing. }\end{array}$ \\
\hline Bel 23 & $1-23$ & $\begin{array}{l}\text { Soil name (WRB/RSCS): Post-ornithogenic } \\
\text { Grey- } \\
\text { humus } \\
\text { Lithosol/Post-ornithogenic grey-humus } \\
\text { Lithozem }\end{array}$ & $\begin{array}{l}\text { Glaucescent-gray horizon. } \\
\text { Less ornithogenic soil processing. } \\
\text { Redoxymorphic signs appear in the lower } \\
\text { part of the horizon. }\end{array}$ \\
\hline Bel 24 & Freshbar & $\begin{array}{l}\text { The top of a weathered rocky highwall near } \\
\text { lighthouses on the east coast of Ardley Island. } \\
\text { The place of active life of the penguin colony. } \\
\text { The surface is completely covered by guano } \\
\text { layer. } \\
\text { Soil name (WRB/RSCS): Turbic } \\
\text { Ornithosol/Cryoturbated Ornithogenic soil }\end{array}$ & \\
\hline Bel 25 & $0-1$ & \multirow{3}{*}{$\begin{array}{l}\text { East coast of Ardley Island. The surface is } \\
\text { covered by moss vegetation (projective cove } \\
\text { is about } 70 \% \text { ). } \\
\text { Feathers of penguins and other birds are on } \\
\text { the surface. } \\
\text { Soil name (WRB/RSCS): Post-ornithogenic } \\
\text { Grey-humus } \\
\text { Lithosol/Post-ornithogenic grey-humus } \\
\text { Lithozem }\end{array}$} & $\begin{array}{l}\text { Peat horizon. } \\
\text { Brownish color of plant debris. } \\
\text { Low decomposition degree. }\end{array}$ \\
\hline Bel 25 & $1-4$ & & $\begin{array}{l}\text { Dark grey-brown horizon. } \\
\text { Traces of humus accumulation and } \\
\text { accumulation of minerals subjected to } \\
\text { ornithogenic impact. } \\
\text { Sandy loam. }\end{array}$ \\
\hline Bel 25 & $4-30$ & & $\begin{array}{l}\text { Transition horizon to the parent rock. } \\
\text { Dun color. } \\
\text { Sandy loam. } \\
\text { Inclusions of medium rounded rocky } \\
\text { material. }\end{array}$ \\
\hline \multicolumn{4}{|c|}{ Non-ornithogenic soils } \\
\hline Bel 5 & $0-2$ & $\begin{array}{l}\text { Small plot covered by mossy vegetation. } \\
\text { Covers the surface of fine-grained material }\end{array}$ & $\begin{array}{l}\text { Peat horizon. } \\
\text { Brownish color of plant debris. } \\
\text { Low decomposition degree. }\end{array}$ \\
\hline Bel 5 & $2-16$ & $\begin{array}{l}\text { Soil name (WRB/RSCS): Histic Spodic } \\
\text { Cryosol/Peat Cryoturbated } \\
\text { Podbur underlain by permafrost }\end{array}$ & $\begin{array}{l}\text { Brown horizon. } \\
\text { Sandy loam. } \\
\text { Inclusions of small boulders. }\end{array}$ \\
\hline Bel 26 & $0-1$ & $\begin{array}{l}\text { Bellingshausen Station. Top of a flat hill. Moss- } \\
\text { lichen cover. There are a lot of detrital material } \\
\text { on the surface }(40-50 \mathrm{~cm}) .\end{array}$ & $\begin{array}{l}\text { Peat horizon. } \\
\text { Brownish color of plant debris. } \\
\text { Low decomposition degree. }\end{array}$ \\
\hline Bel 26 & $1-6$ & \multirow{2}{*}{$\begin{array}{l}\text { Soil name (WRB/RSCS): } \\
\text { Histic Spodic } \\
\text { Cryosol/Peat Cryoturbated } \\
\text { Podbur underlain by permafrost }\end{array}$} & $\begin{array}{l}\text { Light brown-gray horizon. } \\
\text { Sandy loam. } \\
\text { Clarified lens as a sign of a podzolic } \\
\text { (eluvial) process. }\end{array}$ \\
\hline Bel 26 & $6-27$ & & $\begin{array}{l}\text { Brown coffee color. } \\
\text { Bfe horizon. } \\
\text { Sandy loam. }\end{array}$ \\
\hline
\end{tabular}

Bellingshausen Station. The area between residential buildings and diesel power plant. Waterlogging. According to the drilling station, the

Bel $27 \quad 0-5 \quad$ permafrost is at a depth of 4 meters. Soil name (WRB/RSCS):

Hyperskeletic Turbic

Technosol/Cryoturbated

Technozem underlain by permafrost 
Active layer thickness and dynamics in the studied area have been previously investigated. Permafrost table depths for the area of this study have been previously evaluated by vertical electrical resistivity sounding (Alekseev and Abakumov, 2020b). It was found that permafrost table lies at the depths of We found that permafrost table depth ranged between 89 and $100 \mathrm{~cm}$ in the area of our study.

\section{Laboratory analyses}

All chemical and biological parameters, described in the paper, were measured in soil fine earth, sieved through a 2-mm sieve. Standard soil analyzes ( $\mathrm{pH}, \mathrm{C}$ and $\mathrm{N}$ content) were performed according to conventional methods: C-H-N analyzer (Varie EL MAX, Elementar, Germany) were used for carbon and nitrogen content determination and $\mathrm{pH}$ was measured in solution - soil to water - with ratio of $1: 25$ (Vorobyova, 2006). A controlled laboratory incubation was carried out during the mineralization experiment. The experiment was carried out in five replicates for each soil horizon (collected from polypedones with an area of $2 \times 2 \mathrm{~m}$ ). $\mathrm{CO}_{2}$ emissions were determined using the method described by Anderson (1982). Plastic cylinders $10 \mathrm{~cm}$ in diameter and $20 \mathrm{~cm}$ in height were used for work. $10 \mathrm{~g}$ in case of mineral soil and $5 \mathrm{~g}$ in case of organic material were placed in the cylinder during a controlled laboratory incubation. The cylinders with soil samples containing soil moisture of approximately $60 \%$ of water holding capacity were then placed in a beaker with a water at the bottom in order to simulate the field conditions of a paddy. The water content (\%) was controlled during soil incubation. Then soil samples aliquots were brought at $20^{\circ} \mathrm{C}$ in sealed plastic bottles with $1 \mathrm{M} \mathrm{NaOH}$. The amount of $\mathrm{CO}_{2}$ trapped by an alkaline solution was measured by titration after 7 days of incubation. The incubation was carried out for 112 days.

\section{Statistics}

Data normal distribution was verified and a variance analysis (ANOVA) and post hoc test (Fisher's least significant difference) were performed. Differences were considered significant at $p<0.05$.

Statistical data processing and analysis were carried out using standard methods in software packages MS Excel 2016, Past (version 3.20), Statistica 64 (version 10).

\section{Results}

\section{General soil properties}

The studied soils differ significantly in terms of $\mathrm{C}$ and $\mathrm{N}$ content (Table 2). The content of carbon increased due to the ornithogenic factor impact on the topsoil horizon. Upper horizons of ornithogenic soils have in average $4.5 \% \mathrm{C}$ content while non-ornithogenic soils have less content of $\mathrm{C}$ in topsoil - 3.3\%. Maximum of C content has samples of Deschampsia Antarctica and Freshbar (7.5 and 20\% respectively). An accumulation of ornithogenic origin organic matter in humus horizons was also observed that unambiguously indicates the most important role of birds in the substances transfer from their coastal zone to the glacier surface. At the same time, organic matter does not remain "functionally dead", but, due to its dark color, promotes localized ice melting and the formation of microdepressions.

The $\mathrm{C}$ content, with regard to mineral horizons, was generally comparable to similar indicators at control plots. Decreasing of organic matter in lower soil horizons was observed both in ornithogenic and nonornithogenic soils. Ornithogenic factor had a low impact on mineral horizons. Exactly the same picture is in case of $\mathrm{N}$ content: average values in upper horizons are 0.7 and $0.3 \%$ in ornithogenic and non-ornithogenic soils respectively. These data differ significantly $(\mathrm{p}<0.05)$.

This accumulation of organic matter of ornithogenic origin is confirmed by both an increased concentration of total organic carbon compared to non-ornithogenic soil samples, and a lower $\mathrm{C} / \mathrm{N}$ ratio there - the most important indicator of the metabolism of any soil. The $\mathrm{C} / \mathrm{N}$ ratio decreased two-fold in ornithogenic areas, because bird factor induced the organic residues mineralization. Thus, the ornithogenic factor affects not only soil formation in the traditional meaning (Parnikoza et al., 2015), but also the formation of soil-like bodies formed in places where cryoconites accumulate.

Analysis of $\mathrm{pH}_{\mathrm{H} 20}$ values (water extract) in soils showed the predominance of close to neutral values (5.6 $<\mathrm{pH}<6.5)$ in humus horizons and weakly acidic $(5.1<\mathrm{pH}<5.5)$ in lower horizons (under peat horizons) in case of ornithogenic soils; the predominance of neutral and close to neutral values $(5.6<\mathrm{pH}<7.5)$ in humus horizons and weakly alkaline and alkaline reactions $(7.0<\mathrm{pH}<8.5)$ in lower horizons in case of nonornithogenic soils (Table 2).

It should be noted that the studied ornithogenic soils are characterized by significant acidification of the fine earth both due to the organic acids that produced plants (mosses, Deschampsia antarctica) inhabit these soils and the decomposition products of the organic matter guano. 
Table 2. General soil properties.

\begin{tabular}{|c|c|c|c|c|}
\hline Plot, depth, cm & C, \% & $\mathrm{N}, \%$ & $\mathrm{C} / \mathrm{N}$ & $\mathrm{pH}_{\mathrm{H} 2 \mathrm{O}}$ \\
\hline \multicolumn{5}{|c|}{ Ornithogenic soils } \\
\hline Bel 12, 0-2 & $5.42 \pm 0.67$ & $0.63 \pm 0.02$ & 8.63 & 4.9 \\
\hline Bel 12, 2-12 & $3.98 \pm 0.45$ & $0.42 \pm 0.03$ & 9.48 & 5.9 \\
\hline Bel 14, 0-2 & $4.98 \pm 0.24$ & $0.88 \pm 0.05$ & 5.66 & 6.0 \\
\hline Bel 14, 2-15 & $2.32 \pm 0.78$ & $0.43 \pm 0.05$ & 5.40 & 6.9 \\
\hline Bel 16, Deschampsia antarctica & $7.45 \pm 0.45$ & $0.89 \pm 0.12$ & 8.37 & 5.9 \\
\hline Bel 17, 0-2 & $5.32 \pm 0.21$ & $0.53 \pm 0.03$ & 8.10 & 6.0 \\
\hline Bel 17, 2-7 & $4.30 \pm 0.65$ & $0.45 \pm 0.06$ & 7.98 & 6.2 \\
\hline Bel 23, 0-1 & $4.31 \pm 0.23$ & $0.53 \pm 0.03$ & 8.10 & 5.9 \\
\hline Bel 23, 1-23 & $2.34 \pm 0.93$ & $0.24 \pm 0.01$ & 9.75 & 5.5 \\
\hline Bel 24, Freshbar & $20.01 \pm 0.25$ & $6.12 \pm 0.01$ & 3.27 & 5.0 \\
\hline Bel 25, 0-1 & $1.56 \pm 0.32$ & $0.22 \pm 0.02$ & 7.09 & 5.5 \\
\hline Bel 25, 1-4 & $2.02 \pm 0.51$ & $0.45 \pm 0.02$ & 4.49 & 5.6 \\
\hline Bel 25, 4-30 & $1.02 \pm 0.05$ & $0.12 \pm 0.01$ & 8.50 & 5.4 \\
\hline \multicolumn{5}{|c|}{ Non-ornithogenic soils } \\
\hline Bel 5, 0-2 & $3.54 \pm 0.12$ & $0.40 \pm 0.04$ & 8.85 & 5.7 \\
\hline Bel 5, 2-16 & $1.67 \pm 0.15$ & $0.21 \pm 0.09$ & 7.95 & 6.0 \\
\hline Bel 26, 0-1 & $3.31 \pm 0.67$ & $0.38 \pm 0.11$ & 8.71 & 5.8 \\
\hline Bel 26, 1-6 & $2.21 \pm 0.84$ & $0.23 \pm 0.02$ & 9.61 & 7.8 \\
\hline Bel 26, 6-27 & $1.02 \pm 0.54$ & $0.12 \pm 0.03$ & 8.50 & 7.0 \\
\hline Bel 27, 0-5 & $3.21 \pm 0.65$ & $0.22 \pm 0.03$ & 14.59 & 5.9 \\
\hline $\begin{array}{l}\text { Post hoc test Ornithogenic soils - } \\
\text { Non-ornithogenic soils }\end{array}$ & $\mathrm{p}<0.05$ & $\mathrm{p}<0.05$ & 0.07 & $\mathrm{p}<0.05$ \\
\hline Singnificance of differences & Significant & Significant & Insignificant & Significant \\
\hline
\end{tabular}

\section{$\mathrm{CO}_{2}$ mineralization rates}

Mineralization rates of soil organic matter in upper horizons of ornithogenic soils (Bel 12, Bel 14, Bel 24) turned out to be statistically significantly higher than in non-ornithogenic soils $(p<0.05)$ (Table 3 , Figure 2 , 3 ). The cumulative production of $\mathrm{C}-\mathrm{CO}_{2}$ by the upper horizons of ornithogenic soils averaged $373.9 \mathrm{mg} \mathrm{C}$ $\mathrm{CO}_{2} / 100 \mathrm{~g}$, by non-ornithogenic soils - almost 2.5 times less. Values of $\mathrm{C}_{-} \mathrm{CO}_{2}$ cumulative production by the lower, non-surface horizons of ornithogenic soils were comparable to those of non-ornithogenic soils.

Table 3. Average $\mathrm{CO}_{2}$ emission rates, $\mathrm{mg} \mathrm{CO}_{2} / 100 \mathrm{~g}$ soil/day.

\begin{tabular}{|c|c|c|c|c|c|}
\hline \multirow{2}{*}{ Plot, depth, cm } & \multicolumn{5}{|c|}{ Weeks } \\
\hline & $1-3$ & $4-7$ & 8-11 & $12-15$ & 16-19 \\
\hline \multicolumn{6}{|c|}{ Ornithogenic soils } \\
\hline Bel 12, 0-2 & 141.08 & 66.17 & 65.00 & 53.33 & 48.35 \\
\hline Bel 12, 2-12 & 24.04 & 31.58 & 27.05 & 24.90 & 19.08 \\
\hline Bel 14, 0-2 & 131.68 & 70.87 & 87.69 & 68.28 & 55.24 \\
\hline Bel 14, 2-15 & 21.96 & 19.24 & 32.25 & 20.99 & 16.26 \\
\hline Bel 16, Deschampsia antarctica & 20.64 & 19.33 & 26.94 & 21.21 & 16.76 \\
\hline Bel 17, 0-2 & 15.16 & 13.44 & 15.69 & 17.69 & 20.27 \\
\hline Bel 17, 2-7 & 20.17 & 21.26 & 24.08 & 20.12 & 17.98 \\
\hline Bel 23, 1-23 & 39.03 & 32.64 & 45.57 & 43.16 & 26.14 \\
\hline Bel 24, Freshbar & 84.72 & 62.52 & 73.08 & 55.82 & 51.72 \\
\hline Bel 25, 1-4 & 25.34 & 23.85 & 23.72 & 20.98 & 20.32 \\
\hline Bel 25, 4-30 & 31.62 & 23.18 & 32.83 & 24.83 & 18.43 \\
\hline \multicolumn{6}{|c|}{ Non-ornithogenic soils } \\
\hline Bel 5, 0-2 & 66.88 & 54.46 & 84.77 & 66.32 & 51.67 \\
\hline Bel 5, 2-16 & 29.85 & 28.12 & 24.36 & 26.89 & 22.27 \\
\hline Bel 26, 0-1 & 87.27 & 79.87 & 86.03 & 84.60 & 62.85 \\
\hline Bel 26, 1-6 & 21.46 & 18.95 & 28.44 & 21.88 & 16.84 \\
\hline Bel 26, 6-27 & 21.97 & 20.54 & 23.81 & 25.09 & 17.90 \\
\hline Bel 27, 0-5 & 22.17 & 18.83 & 21.82 & 20.19 & 16.21 \\
\hline $\begin{array}{l}\text { Post hoc test Ornithogenic soils - } \\
\text { Non-ornithogenic soils }\end{array}$ & $\mathrm{p}<0.05$ & $\mathrm{p}<0.05$ & 0.46 & 0.34 & 0.49 \\
\hline Singnificance of differences & Significant & Significant & Insignificant & Insignificant & Insignificant \\
\hline
\end{tabular}


The data obtained (Table 3) showed that the total amount of $\mathrm{CO}_{2}$ released from the soil has 2 peaks over time: the first peak - at 1-3 weeks, at the very beginning of the experiment, the second peak - at 8-11 weeks. This tendency is typical almost for all studied soils of both ornithogenic and non-ornithogenic origin. The post-hoc test showed essential differences between ornithogenic and non-ornithogenic plots only for the first two experiment periods $\left(1-3\right.$ and 4-7 weeks) $(\mathrm{p}<0.05)$. The decrease in the rate of $\mathrm{CO}_{2}$ release during the first month of soil samples incubation is apparently due to the consumption of easily available substrates. An increase in the rate of $\mathrm{CO}_{2}$ production by soil horizons in the second half of the incubation period (3-4 months) is associated with the mineralization of inaccessible and deficient components (as sources of energy and nutrition) of soil organic matter by microorganisms.

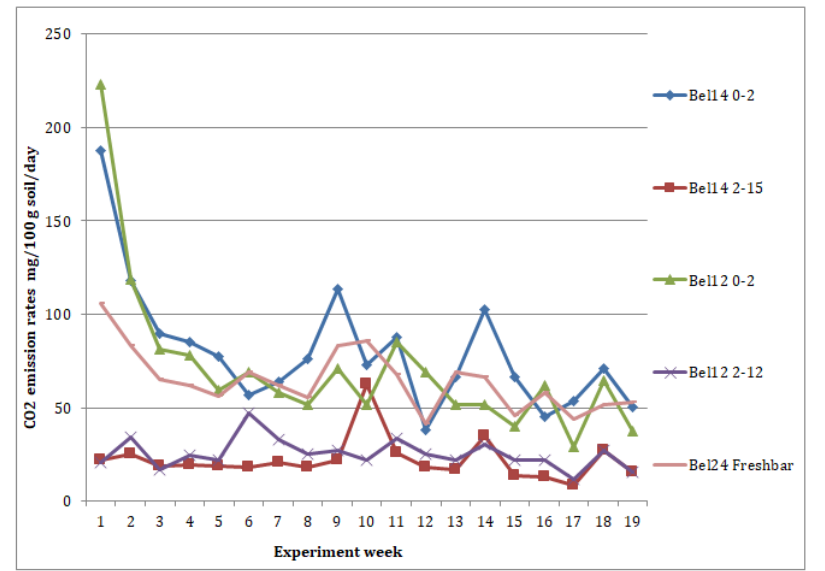

Figure 2. $\mathrm{CO}_{2}$ emission rates in ornithogenic soils, $\mathrm{mg} / 100 \mathrm{~g}$ soil/day

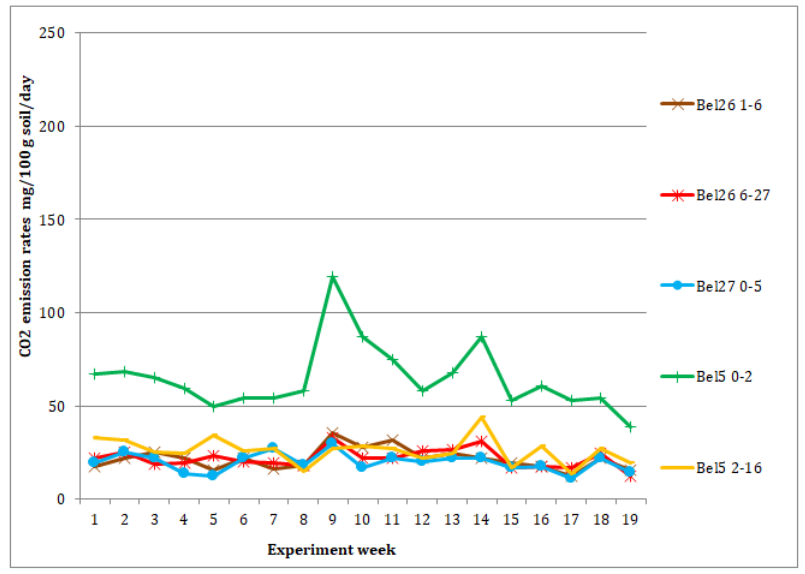

Figure 3. $\mathrm{CO}_{2}$ emission rates in non-ornithogenic soils, $\mathrm{mg} / 100 \mathrm{~g}$ soil/day

\section{$\mathrm{CO}_{2}$ emission and SOM stability to mineralization}

The amount of $\mathrm{C}-\mathrm{CO}_{2}$ produced by the incubated soil simultaneously characterizes both the metabolic activity of soil microorganisms and the ability of organic matter to mineralize. The content of potentially mineralizable carbon in the soil gives a general idea of the mineralization capacity of organic matter: the greater a proportion of potentially mineralizable carbon (PMC), the less stable soil organic matter and more susceptible to various mineralizing effects (Semenov et al., 2008, 2009; Kadono et al., 2009). The data on the rate of organic matter mineralization (Table 4) show that the total amount of $\mathrm{CO}_{2}$ released from studied soil samples decreased over time. This tendency is more pronounced for upper soil horizons than for lower organo-mineral. A maximum of PMC content was found in the upper horizons of ornithogenic soils (Bel 12, Bel 14) $(38.5 \mathrm{~g} / \mathrm{kg})$, while the proportion of potentially mineralizable carbon in the Bel 24 Freshbar soil, which has the highest $C$ content $(20.01 \pm 0.25 \%)$, was 1.7 times lower (Table 4$)$. The data of mineralization degree according to the $\mathrm{C}_{-} \mathrm{CO}_{2}$ content (table 4), as well as in the case of $\mathrm{CO}_{2}$ release intensity, show 2 peaks in time. The difference between $\mathrm{C}-\mathrm{CO}_{2} / \mathrm{TOC}$ ratio values were statisticaly significant for topsoil horizons (ornithogenic and non-ornithogenic) $(\mathrm{p}<0.05)$.

The PMC percentage proportion of the total amount of organic carbon characterizes the mineralization capacity or stability of soil organic matter: the wider this ratio, the higher the stability of organic matter (Semenov et al., 2008; Kadono et al., 2009). The data obtained showed that ornithogenic soil (Bel 25) was characterized by the highest mineralization capacity - 84.69\%. The mineralization capacity of the upper horizons in non-ornithogenic soils was, on average, lower than in ornithogenic soils. However, the opposite picture is observed for the lower horizons - ornithogenic soils are characterized by a reduced proportion of PMC in the total amount of organic matter. Therefore, a significant change of SOM quality occurs under the influence of the ornithogenic factor.

The stabilization of organic matter are the processes that increase its resistance to biotic and abiotic influences and lead to an increase in the turnover time of organic matter in the soil due to the acquired protected state. Destabilization is the reverse process of stabilization, as a result of which components of organic matter become less resistant to degradation and more available for microorganisms use (Swift, 2001; Six et al., 2006). The highest stability of organic matter was found for ornithogenic soils (Table 4). The rate of mineralization in lower mineral horizons of studied soils is lower than in surface horizons. Probably, the composition of soil humic acids (the ratio of carboxyl groups and aliphatic components) changes under the influence of the ornithogenic factor, which can cause a change in the mineralization rate of organic matter. Therefore, structural changes in the organic matter system under the influence of the ornithogenic factor play an essential role in the organic matter stabilization for soils (Ejarque and Abakumov, 2016). 
Table 4. Portions of $\mathrm{C}$ mineralized on weeks and portion of total minerlized carbon to TOC content.

\begin{tabular}{|c|c|c|c|c|c|c|c|}
\hline \multirow{2}{*}{ Plot } & \multirow{2}{*}{ Depth, cm } & \multicolumn{5}{|c|}{ 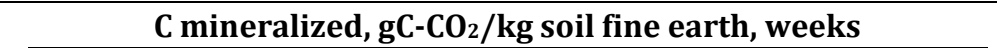 } & \multirow{2}{*}{$\mathrm{C}-\mathrm{CO}_{2} / \mathrm{TOC}, \%$} \\
\hline & & $1-3$ & $4-7$ & $8-11$ & $12-15$ & $16-19$ & \\
\hline \multicolumn{8}{|c|}{ Ornithogenic soils } \\
\hline Bel 12 & $0-2$ & 38.55 & 18.08 & 17.76 & 14.57 & 13.21 & 14.07 \\
\hline Bel 12 & $2-12$ & 6.57 & 8.63 & 7.39 & 6.80 & 5.21 & 60.59 \\
\hline Bel 14 & $0-2$ & 35.98 & 19.36 & 23.96 & 18.66 & 15.09 & 13.84 \\
\hline Bel 14 & $2-15$ & 6.00 & 5.26 & 8.81 & 5.73 & 4.44 & 38.66 \\
\hline Bel 16 & Deschampsia antarctica & 5.64 & 5.28 & 7.36 & 5.80 & 4.58 & 132.14 \\
\hline Bel 17 & $0-2$ & 4.14 & 3.67 & 4.29 & 4.83 & 5.54 & 128.45 \\
\hline Bel 17 & $2-7$ & 5.51 & 5.81 & 6.58 & 5.50 & 4.91 & 78.07 \\
\hline Bel 23 & $1-23$ & 10.66 & 8.92 & 12.45 & 11.79 & 7.14 & 21.94 \\
\hline Bel 24 & Freshbar & 23.15 & 17.08 & 19.97 & 15.25 & 14.13 & 86.45 \\
\hline Bel 25 & $1-4$ & 6.92 & 6.52 & 6.48 & 5.73 & 5.55 & 29.18 \\
\hline Bel 25 & 4-30 & 8.64 & 6.33 & 8.97 & 6.78 & 5.03 & 11.81 \\
\hline \multicolumn{8}{|c|}{ Non-ornithogenic soils } \\
\hline Bel 5 & $0-2$ & 18.27 & 14.88 & 23.16 & 18.12 & 14.12 & 19.37 \\
\hline Bel 5 & $2-16$ & 8.16 & 7.68 & 6.66 & 7.34 & 6.08 & 20.47 \\
\hline Bel 26 & $0-1$ & 23.84 & 21.82 & 23.50 & 23.12 & 17.17 & 13.88 \\
\hline Bel 26 & $1-6$ & 5.86 & 5.18 & 7.77 & 5.98 & 4.60 & 37.68 \\
\hline Bel 26 & $6-27$ & 6.00 & 5.61 & 6.50 & 6.85 & 4.89 & 16.99 \\
\hline Bel 27 & $0-5$ & 6.06 & 5.14 & 5.96 & 5.52 & 4.43 & 53.00 \\
\hline \multicolumn{2}{|c|}{$\begin{array}{l}\text { Post hoc test Ornithogenic soils - } \\
\text { Non-ornithogenic soils }\end{array}$} & $\mathrm{p}<0.05$ & $\mathrm{p}<0.05$ & 0.47 & 0.34 & 0.49 & $\mathrm{p}<0.05$ \\
\hline \multicolumn{2}{|c|}{ Singnificance of differences } & Significant & Significant & Insignificant & Insignificant & Insignificant & Significant \\
\hline
\end{tabular}

\section{Discussion}

Soils exposed to ornithogenic factors showed significant differences in general chemical properties. Firstly, essential changes in the TOC content have been observed there due to a great role of guano organic matter in the soil-forming process. Non-ornithogenic soils are characterized by decreased nitrogen and carbon content, therefore it in turn increases $\mathrm{C} / \mathrm{N}$ ratio compared to ornithogenic soil. These results correspond with data of Abakumov (2018) and Parnikoza et al. (2015), who showed a significant alteration in the quality of organic matter that occurs in post-ornithogenic soil. What is more, $\mathrm{pH}$ values decreased compared to ornithogenic soil because of organic acids that produced plants (mosses, Deschampsia antarctica) inhabit these soils and the decomposition products of the organic matter guano.

Cluster analysis was carried out in order to group studied plots according to the content of potentially mineralizable carbon in soils. Dendrograms of studied areas similarity are shown in Figure 4. Clustering was performed using a UPGMA method (unweighted pair group method with arithmetic mean). Cluster analysis, carried out using the Jaccard index and the single bond (nearest neighbor) method, identified two groups according to the principle of soil genesis: ornithogenic and non-ornithogenic soils (Figure 4), separately indicating the group of ornithogenic soils with the maximum rates of soil organic matter mineralization (Bel14 and Bel12). The merging of these two clusters occurs when the similarity rate is slightly higher than $50 \%$. The noted soils grouping reflects the transformation processes specificity of organic substances in studied soils. Apparently, soils grouping is due to the predominance of organic matter transformation processes caused by the ornithogenic factor.

At the same time, a proportion of organic carbon mineralized during the experiment (\%) was lower in nonornithogenic samples than in ornithogenic ones. These data correspond with findings of Alekseev and Abakumov (2020a), who showed a significant alteration in the organic matter quality in post-ornithogenic soils. It has already shown that aromatic compounds portion is slightly more in soils formed on substances carried by birds compared to soils under monospecies of bryophytes or lichens communities (Abakumov and Fattakhova, 2015; Abakumov and Alekseev, 2018). This is explained by the fact that birds use mostly the Deschampsia antarctica remains for building nests, which contain an increased proportion of phenylpropane organic precursors (Alekseev and Abakumov, 2020a). This can affect the rate of SOM mineralization in postornithogenic and non-ornithogenic soils. Therefore, structural changes in a system of soil organic matter play an important role in its stabilization for post-ornithogenic soils, besides the SOM oxidation degree regulates mineralization rates and other indicators of the quality of post-ornithogenic SOM. Therefore, it can 
be concluded that the most stabilized SOM is found for ornithogenic materials, where the humification degree and TOM transformation are the highest. Processes of organic matter stabilization begin immediately from the moment it enters the soil, where it undergoes destruction, decomposition and mineralization. Soil microorganisms are active agents not only for biodegradation of organic matter, but also for its stabilization. Thus, there are more microorganisms in ornithogenic soil that can lead to acceleration of mineralization rates and organic matter stabilization.

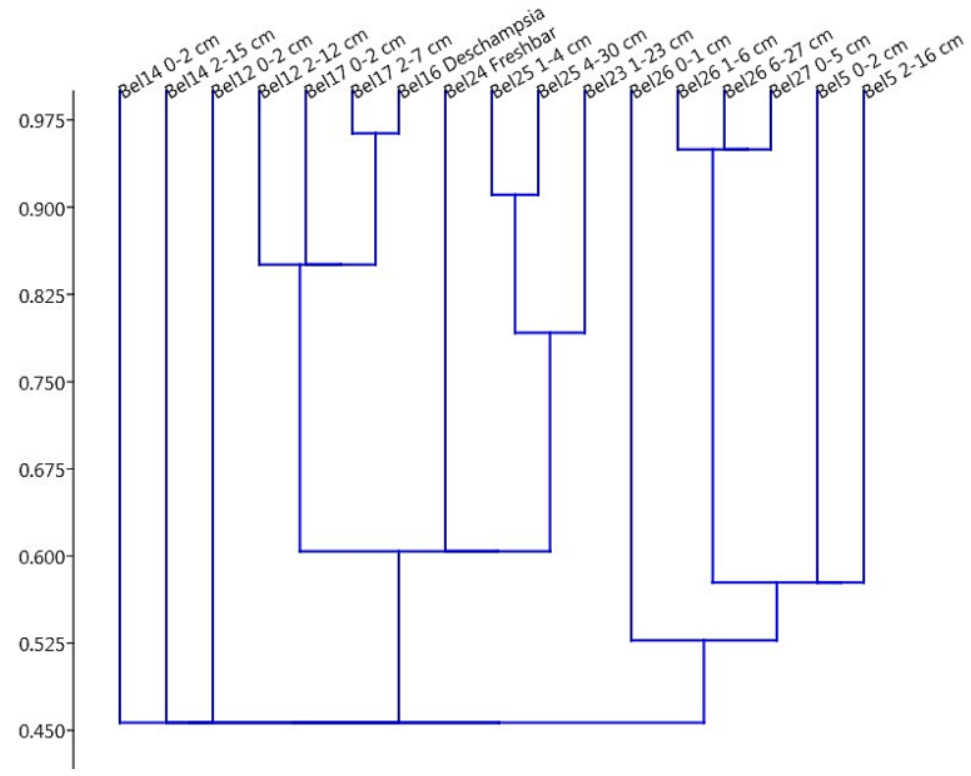

Figure 4. Dendrograms of studied areas similarity (Jaccard index, single bond (nearest neighbor) method).

Organic matter mineralization in soils occurs according to the various factors acting on them. On the basis of the results obtained, an attempt was made to identify the main environmental factors that determine the mineralization rate as a value on which these factors can have a direct effect.

The following factors, that could be assessed directly, or reflected in a certain gradation by expert assessment method, were identified:

— factors describing the genesis of the studied soils - the effect of the ornithogenic factor;

- factors describing the vegetation cover of the studied areas: moss-lichen cover, Deschampsia antarctica and guano, ornithogenic material;

- factors that describe soil characteristics and the depth of horizons: $\mathrm{pH}, \mathrm{C}$ and $\mathrm{N}$ content, $\mathrm{C} / \mathrm{N}$ ratio.

A degree of factors influence was assessed using the Canonical Correspondence Analysis (CCA) (Figure 5). Three factors that have the greatest impact on the rate of soil organic matter mineralization can be distinguished: $\mathrm{pH}, \mathrm{C}$ content and origin (ornithogenic/non-ornithogenic soils). The depth of soil horizons influence on mineralization in lesser extent.

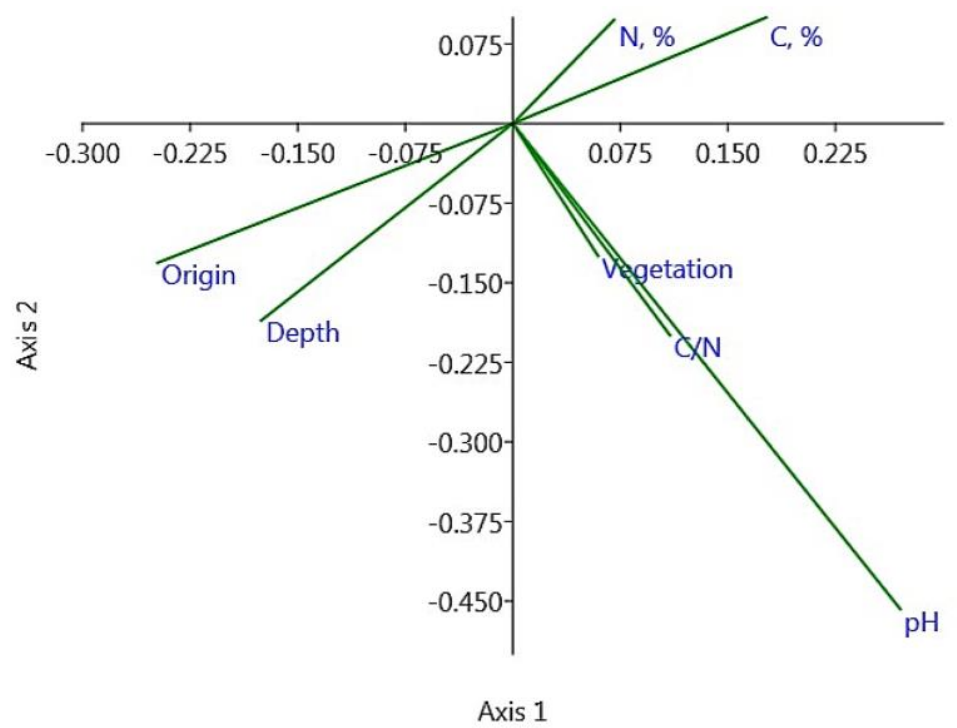

Figure 5. Environmental factors affecting the rate of organic matter mineralization in the studied soils. 
Finally, results obtained suggest that additional laboratory incubation experiments are needed for investigation of various Antarctic post-ornithogenic environments in order to determine the role of the origin and quality of SOM and soil type in the rate of SOM stabilization and to better understand possible post-ornithogenic mineralization risks.

\section{Conclusion}

Soil processes in post-ornithogenic soils differ from those in not subjected to this factor soils. Study results indicate that soils under the current ornithogenic influence are characterized by an increased content of carbon and nitrogen with a rather narrow ratio of $\mathrm{C} / \mathrm{N}$. The amount of $\mathrm{CO}_{2}$, in general, released over the entire experiment period is quite large for both ornithogenic and non-ornithogenic soils.

Comparing the resistance parameters of soil organic matter to mineralization, it can be concluded that the most stabilized organic matter is characteristic of ornithogenic soils of the studied area. Thus, the avifauna favors and increases the rate of the mineralization process by several times. An acceleration in the organic matter mineralization rate leads to an increase in nutrients amount available to plants, as in the case of the studied soils.

The accumulation of guano, nests building by penguins and other birds lead to the formation of specific soil polypedones. Apart from direct birds influence on soils localities of ornithogenic edaphotopes, their influence spreads through partial dissolution and substances migration in the landscape, nitrification, which leads to a post-ornithogenic successions start and a radical change in the local geochemistry of the landscape.

Therefore, ornithogenic soil formation is a special phenomenon of pedogenesis in the Southern Hemisphere, which expressed in the most diverse forms of morphological organization and processes of biogeochemical transformation. Thus, further study of $\mathrm{CO}_{2}$ emissions is needed, with the aim of better characterizing postornithogenic SOM dynamics creating an approach to model this process.

\section{Acknowledgments}

This study was supported Grant of Saint-Petersburg State University "Urbanized ecosystems of the Russian Arctic: dynamics, state and sustainable development" and Russian Foundation for Basic Research, projects No: 19-05-50107 and 19-54-18003. The authors gratefully acknowledge Russian Antarctic Expedition, especially the head of seasonal expedition 2017-2018 V.N. Churun, for providing scientific and logistic support during the field work. Carbon was measured in Research park of Saint-Petersburg State University, Chemical Analysis and Materials Research Centre".

\section{References}

Abakumov, E., Alekseev, I., 2018. Stability of soil organic matter in Cryosols of the maritime Antarctic: insights from ${ }^{13} \mathrm{C}$ NMR and electron spin resonance spectroscopy. Solid Earth 9: 1329-1339.

Abakumov, E., Mukhametova, N., 2014. Microbial biomass and basal respiration of selected Sub-Antarctic and Antarctic soils in the areas of some Russian polar stations. Solid Earth 5: 705-712.

Abakumov, E.V., 2010. The sources and composition of humus in some soils of West Antarctica. Eurasian Soil Science 43: 499-508.

Abakumov, E.V., 2014a. Micromorphological characteristics of ornithogenic soil formation in Antarctica. Russian Ornithology Journal 23(1030): 2353-2357. [in Russian].

Abakumov, E.V., 2014b. Zoogenic pedogenesis as the main biogenic soil process in Antarctica. Russian Ornithology Journal 23(972): 576-584. [in Russian].

Abakumov, E.V., 2018. Birds role in nutrient regime formation in soils of the Fildes Peninsula (West Antarctica). Russian Ornithology Journal 27(1623): 2757-2760. [in Russian].

Abakumov, E.V., Fattakhova, Yu.M., 2015. Structural composition of humic substances in ornithogenic soils of Antarctica according to nuclear magnetic resonance (13-C). Russian Ornithology Journal 24(1165): 2463-2466. [in Russian].

Abakumov, E.V., Lupachev, A.V., 2011/2012. Soil diversity of Antarctic terrestrial ecosystems (in the areas of Russian Antarctic Stations). Ukrainian Antarctic Journal 10-11: 222-228.

Abakumov, E.V., Lupachev, A.V., Parnikoza, I.Yu., 2018. Ornithogenic soils of Antarctica: diversity, properties, functioning. Proceedings of III International Scientific and Practical Conference "The Natural Environment of Antarctica: Environmental Problems and Protection". 17-19 September 2018. Belarus. pp. 59-61.

Abakumov, E.V., Parnikoza, I.Y., Vlasov, D.Yu., Lupachev, A.V., 2016. Biogenic-abiogenic interaction in Antarctic ornithogenic soils. In: Biogenic-Abiogenic Interactions in Natural and Anthropogenic Systems. FrankKamenetskaya, O.V., Panova, E.G., Vlasov, D.Yu. (Eds.). Springer, pp. 237-248.

Alekseev, I., Abakumov, E., 2020b. Permafrost table depth in soils of Eastern Antarctica oases, King George and Ardley Islands (South Shetland Islands). Czech Polar Reports 10(1): 7-22. 
Alekseev, I., Zverev, A., Abakumov, E., 2020. Microbial communities in permafrost soils of Larsemann Hills, Eastern Antarctica: environmental controls and effect of human impact. Microorganisms 8(8): 1202.

Alekseev, I.I., Abakumov, E.V., 2018. Acid-alkali properties and mesomorphological organization of soils in maritime Antarctica: Fildes Peninsula (King George Island) and Ardley Island (South Shetland Islands). Russian Ornithology Journal 27(1653): 3911-3918. [in Russian].

Alekseev, I.I., Abakumov, E.V., 2020a. Ornithogenic soils of the Antarctic Maritimo: genesis, chemical composition, organic matter. Abstracts of International Scientific Conference "Comprehensive Research of the Natural Environment of the Arctic and Antarctic". 2-4 March 2020. Saint Petersburg. Russia. pp. 170-172. [in Russian].

Anderson, J.P.E., 1982. Soil respiration. In. Methods of soil analysis, Part 2- Chemical and Microbiological Properties, Page, A.L., Keeney, D. R., Baker, D.E., Miller, R.H., Ellis, R. Jr., Rhoades, J.D. (Eds.). ASA-SSSA, Madison, Wisconsin, USA. pp. 831-871.

Bockheim, J.G., 2013. Paleosols in the Transantarctic Mountains: indicators of environmental change. Solid Earth 4: 451459.

Bruun, T.B., Elberling, B., de Neergaard, A., Magid, J., 2015. Organic carbon dynamics in different soil types after conversion of forest to agriculture. Ecosystems 26(3): 272-283.

Campbell, I.B., Claridge, G.G.C., 1987. Antarctica: soils, weathering processes and environment. Elsevier, Amsterdam. $367 p$.

Debasish-Sasha, Kukal, S.S., Bawa, S.S., 2014. Soil organic carbon stock and fractions in relation to land use and soil depth in the degraded shiwaliks hills of lower Hymalayas. Land Degradation and Devevelopment 25(5): 407-416.

Dmitrakova, J., Abakumov, E., 2019. Dynamics of soil organic carbon of reclaimed lands and the related ecological risks to the additional $\mathrm{CO}_{2}$ emission. In: Urbanization: challenge and opportunity for soil functions and ecosystem services. Proceedings of the 9th SUITMA Congress. Vasenev V., Dovletyarova E., Cheng Z., Prokof'eva T., Morel J., Ananyeva, N. (Eds.). Springer Geography. Springer, pp. 97-105.

Ejarque, E., Abakumov, E., 2016. Stability and biodegradability of organic matter from Arctic soils of Western Siberia: insights from ${ }^{13} \mathrm{C}-\mathrm{NMR}$ spectroscopy and elemental analysis. Solid Earth 7: 153-165.

IPCC, 2007. Contribution of Working Group I to the Fourth Assessment Report of the Intergovernmental Panel on Climate Change. Solomon, S., Qin, D., Manning, M., Chen, Z., Marquis, M., Averyt, K.B., Tignor, M., Miller, H.L., (Eds.). Cambridge, United Kingdom, New York, USA. 996p. Available at [Access date: 07.10.2020]: https://archive.ipcc.ch/pdf/assessment-report/ar4/wg1/ar4_wg1_full_report.pdf

Ivanov, A.N., 2013. Ornithogenic geosystems of the North Pacific islands. Moscow. 228p. [in Russian].

Ivanov, A.N., Avessalomova, I.A., 2012. Ornitogenous ecosystems as a geochemical phenomenon of the biosphere. Biosphere 4(4): 385-396. [in Russian].

Kadono, A., Funakawa, S., Kosaki, T., 2009. Factors controlling potentially mineralizable and recalcitrant soil organic matter in humid Asia. Soil Science Plant Nutrition 55(2): 243-251.

Michel, R.F.M., Schaefer, C.E.G.R., Dias, L.E., Simas, F.N.B., Benites, V.M., Mendonça, E.S., 2006. Ornithogenic gelisols (cryosols) from Maritime Antarctica: pedogenesis, vegetation and carbon studies. Soil Science Society of America Journal 70(4): 1370-1376.

Muñoz-Rojas, M., Jordán, A., Zavala, L.M., De la Rosa, D., Abd-Elmabod, S.K., Anaya-Romero, M., 2015. Impact of land use and land cover changes on organic carbon stocks in Mediterranean soils (1956-2007). Land Degradation and Development 26(2): 168-179.

Novara, A., Rühl, J., La Mantia, T., Gristina, L., La Bella, S., Tuttolomondo, T., 2015. Litter contribution to soil organic carbon in the processes of agriculture abandon. Solid Earth 6: 425-432.

Parnikoza, I., Abakumov, E., Korsun, S., Klymenko, I., Netsyk, M., Kudinova, A., Kozeretska, I., 2016. Soils of the Argentine Islands, Antarctica: diversity and characteristics. Polarforschung 86(2): 83-96.

Parnikoza, I.Yu., Abakumov, E.V., Dikiy, I.V., Pilipenko, D.V., Shvidun, P.P., Kozeretskaya, I.A., Kunakh, V.A., 2015. Birds influence on the spatial distribution of Deschampsia antarctica Desv. of Galindez Islands (Argentine Islands, Coastal Antarctica). Bulletin of St. Petersburg State University. Ser. 3: Biology (1): 78-97. [in Russian].

Parras-Alcántara, L., Lozano-García, B., Brevik, E.C., Cerdà, A., 2015. Soil organic carbon stocks assessment in Mediterranean natural areas: a comparison of entire soil profiles and soil control sections. Journal of Environmental Management 155: 219-228.

Peng, F., Quangang, Y., Xue, X., Guo, J., Wang, T., 2015. Effects of rodent-induced land degradation on ecosystem carbon fluxes in an alpine meadow in the Qinghai-Tibet Plateau, China. Solid Earth 6: 303-310.

Pereira, T.T.C., Schaefer, C.E.G.R., Ker, J.C., Almeida, C.C., Aimeida, I.C.C., 2013. Micromorphological and microchemical indicators of pedogenesis in Ornithogenic Cryosols (Gelisols) of Hope Bay, Antarctic Peninsula. Geoderma 193/194: 311-322.

Rein, G., 2013. Smouldering fires and natural fuels. In: Fire phenomena and the earth system: an interdisciplinary guide to fire science. Belcher, C.M. (Ed.). John Wiley \& Sons, Oxford. pp.15-33.

Schuur, E.A.G., McGuire, A.D., Schädel, C., Grosse, G., Harden, J.W., Hayes, D.J., Hugelius, G., Koven, C.D., Kuhry, P., Lawrence, D.M., Natali, S.M., Olefeldt, D., Romanovsky, V.E., Schaefer, K., Turetsky, M.R., Treat, C.C., Vonk, J.E., 2015. Climate change and the permafrost carbon feedback. Nature 520: 171-179.

Semenov, V.M., Ivannikova, L.A., Kuznetsova, T.V., Semenova, N.A., Tulina, A.S., 2008. Mineralization of organic matter and the carbon sequestration capacity of zonal soils. Eurasian Soil Science 41: 717-730. 
Semenov, V.M., Ivannikova, L.A., Tulina, A.S., 2009. Stabilization of organic matter in the soil. Agrochemistry 10: 77-96. [in Russian].

Shishov, L.L., Tonkonogov, V.D., 2004. Classification and diagnostics of Russian soils. Soil Institute of Dokuchayev, Moscow, Russia. 341p. [in Russian].

Simas, F.N.B., Schaefer, C.E.G.R., Filho, M.R.A., Francelino, M.R., Filho, E.I.F., da Costa, L.M., 2008. Genesis, properties and classification of Cryosols from Admiralty Bay, maritime Antarctica. Geoderma 144: 116-122.

Simas, F.N.B., Schaefer, C.E.G.R., Melo, V.F., Albuquerque-Filho, M.R., Michel, R.F.M., Pereira, V.V., Gomes M.R.M., da Costa, L.M., 2007a. Ornithogenic cryosols from Maritime Antarctica: Phosphatization as a soil forming process. Geoderma 138(3-4): 191-203.

Simas, F.N.B., Schaefer, C.E.G.R., Mendonca, E.S., Silva, I.R., Santana, R.M., Ribeiro, A.S.S., 2007b. Organic carbon stocks in permafrost-affected soils from Admiralty Bay, Antarctica. Journal of research of the U.S. Geological Survey 1047: 76-79.

Six, J., Frey S.D., Thrieth, R.K., Batten, K.M., 2006. Bacterial and fungal contributions to carbon sequestration in agroecosystems. Soil Science Society of America Journal 70(2): 555-569.

Swift, R.S., 2001. Sequestration of carbon by soil. Soil Science 166(11): 858-871.

Terauds, A., Chown, S.L., Morgan, F., Peat, H.J., Watts, D.J., Keys, H., Convey, P., Bergstrom, D.M., 2012. Conservation biogeography of the Antarctic. Diversity and Distributions 18(7): 726-741.

Tsibart, A., Gennadiev, A., Koshovskii, T., Watts, A., 2014. Polycyclic aromatic hydrocarbons in post-fire soils of drained peatlands in western Meshchera (Moscow region, Russia). Solid Earth 5: 1305-1317.

Ugolini, F.C., Bockheim, J.G., 2008. Antarctic soils and soils formation in a changing environment: A review. Geoderma 144(1-2): 1-8.

Vorobyova, L.A., 2006. Theory and practice of the chemical soil analysis. GEOS, Moscow, Russia. 400p. [in Russian].

Wasak, K., Drewnik, M., 2015. Land use effects on soil organic carbon sequestration in calcareous Leptosols in former pastureland - a case study from the Tatra Mountains (Poland). Solid Earth 6: 1103-1115.

WRB, 2015. International soil classification system for naming soils and creating legends for soil maps. World Soil Resources Reports No. 106. Food and Agriculture Organization of the United Nations (FA0), Rome, Italy. 192p. Available at [access date: 07.10.2020]: http://www.fao.org/3/i3794en/I3794en.pdf

Yu, B., Stott, P., Di, X.Y., Yu, H.X., 2012. Assessment of land cover changes and their effect on soil organic carbon and soil total nitrogen in Daqing Prefecture, China. Land Degradation and Development 25(6): 520-531.

Zaccone, C., Rein, G., D’Orazio, V., Hadden, R.M., Belcher, C.M., Miano, T.M., 2014. Smouldering fire signatures in peat and their implications for palaeoenvironmental reconstructions. Geochimica et Cosmochimica Acta 137: 134-146.

Zhao, H., Tong, D.Q., Lin, Q., Lu, X., Wang, G., 2012. Effect of fires on soil organic carbon pool and mineralization in a Northeastern China wetland. Geoderma 189-190: 532-539. 